DOI: $10.17805 /$ trudy.2016.5.5

\title{
МОЛОДЕЖНАЯ ПОЛИТИКА В РОССИИ: НЕКОТОРЫЕ ТЕОРЕТИЧЕСКИЕ АСПЕКТЫ
}

\author{
А. Д. Плотников \\ (Московский гуманитарный университет)
}

Аннотация: Статья обосновывает необходимость учета специфики современной молодежи с целью совершенствования и научного обоснования российской молодежной политики в современных условиях.

Ключевые слова: молодежь; дети; молодое поколение; молодежная политика; уровень субъектности молодых людей; проблемы молодежи

\section{YOUTH POLICY IN RUSSIA: THEORETICAL ASPECTS}

\author{
A. D. Plotnikov \\ (Moscow University for the Humanities)
}

Abstract: The article argues in favor of accounting for the specific features of contemporary youth in improving Russia's federal youth policy and providing a new scientific foundation for this policy in contemporary Russia.

Keywords: youth; children; younger generation; youth policy; level of subjectness in young people; youth-related issues

\section{Введение}

Выросшие и социализированные в новых условиях XXI века молодые люди России, частично вобравшие в себя жизненный опыт и мировоззрение старшего поколения, впитавшего советский образ жизни, организуют свою жизнедеятельность, исходя и полученного воспитания и основываясь на современных экономических и социокультурных реалиях. Объясняемая таким положением специфика и особенности юношей и девушек, их частично противоречивые взгляды на все устои, сферы деятельности государства и общества требуют тщательного и объективного анализа состояния, потенциала и мировоззрения молодежи, правильного сопоставления содержания государственной политики в отношении молодого поколения с учетом его реального состояния и, как нам кажется, неординарных воззрений на окружающий мир.

Молодежь объективно и вынужденно росла в обстановке динамичной 
социальной трансформации, в условиях острых и масштабных противоречий, оказалась вовлеченной в процесс коренного разрушения стереотипов поведения российских граждан.

Конечно, в существенным образом изменившихся условиях нам нужна новая молодежная политика, которая носила бы новаторский, оптимально созидательный характер, так как ее главный объект и субъект - молодежь - принципиальным образом трансформировались. Все активнее возрастает уровень субъектности молодых людей в экономической и политической сферах, развитии культуры, религии, формировании новых, гармоничных межнациональных отношений. Все это становится фактически главной характерной особенностью молодежи.

\section{Некоторые аспекты теорий о молодежи}

История исследования проблем молодежи в нашей стране имеет давние корни и традиции. По направленности и назначению они в общем смысле совпадают с изучением в сфере гуманитарных наук вопросов молодежи, анализируемыми в других странах мира, в том числе в Европе и на Американском континенте. В разных регионах мира, как и в России в процессе исторического развития появлялись концепции молодежи, выражавшие ожидания общества от новых поколений и представлявшие собой своеобразное теоретическое зеркало естественного процесса социального саморазвития, сопровождаемого сменой поколений.

Следует отметить, что развитие теорий о молодежи происходило неоднородно, скачками, отражая по всей видимости общественные потребности в той или иной стране, либо регионе мира.

Анализируя теорию о молодежи, следует обратить внимание на то, что одни из них ориентировали на восприятие молодежи как носительницы психофизических свойств жизнедеятельного состояния людей молодости. Другие свидетельствовали о выделении молодежи как культурной группы - сообщества людей, которому присущи определенные культурные свойства и функции.

Третьи акцентировали внимание на молодежь как объект и субъект единого цивилизационного развития - естественного процесса преемственности и смены поколений.

Эти, условно выделенные направления важны для структурного понимания процесса теоретического осмысления сферы жизни и деятельности молодого поколения. Они имеют свою актуальность и сегодня с точки зрения методологии анализа социокультурной динамики, современной теории и практики социализации молодежи.

Для подготовки настоящего материала важное значение имели предшествующее осмысление идей и концепций молодежной политики, ис- 
следование работ И. М. Ильинского. В книгах И. М. Ильинского делается философский анализ молодежи, трактуемой как ценность, ставится вопрос о новых поколениях в свете глобальных вызовов XXI века. Здесь концептуализируется молодежная проблематика и формируются подходы к молодежной политике, адекватной нашему времени. И делается это на основе авторского подхода к изучению истории и современной практики (Ильинский, 1999, 2001, 2005, 2006, 2008, 2009аbс; Молодежь России ..., 1993, 1995).

При написании данного материала большое значение имели также Таковы труды В. Т. Лисовского (Лисовский, 1998, 2000), обобщающие работы по теоретическим вопросам социологии молодежи А. И. Ковалевой и В. А. Лукова, которые значительно продвинули вперед теоретическое осмысление молодежи в свете нового социального опыта (Жулковска, Ковалева, Луков, 2003; Ковалева, 1995, 1996, 2001, 2003, 2004, 2006ab, 2007; Ковалева, Богданова, 2012; Ковалева, Луков, 1999, 2012; Луков, Луков, Ковалева, 2006; Kowalowa, Łukow, 2003; Луков, 2007, 2012; Государственная молодежная ..., 2013: Электр. ресурс).

В современных условиях актуализируется необходимость теоретического осмысления «новой молодежи», разработки фундаментальных исследований в области молодежной политики, формировании магистральной Концепции создания условий для воспитания жизнедеятельного поколения - от момента рождения человека до окончания молодежного возраста. По нашему мнению, в данной Концепции должен быть сделан упор на неразделимый процесс воспитания, охватывающий подрастающее поколение как из числа детей, так и молодежи. Данный научно-методологический документ должен быть ориентирован также на постоянное повышение уровня субъектности, активной деятельности детей и молодежи на всех этапах их развития.

Концепция должна носить, на наш взгляд, исключительно межведомственный, междисциплинарный характер, охватывая сферы экономики, образования, воспитания, демографии, здравоохранения, профессиональной подготовки, культуры. Магистральной линией внутренней политики в отношении молодежи должно стать стремление государства и общества к максимально возможному развитию личностного потенциала молодых людей и создание в этой связи комплекса условий для самореализации юного поколения с целью обеспечения личного, семейного и общественного благополучия.

Важным вопросом теоретических разработок о молодежи и молодежной политике является анализ понятийного аппарата, от адекватности понимания которого зависит судьба любого концептуального труда или иных изысканий, касающихся проблем молодого поколения. Не вдаваясь в исследование многочисленных определений молодежной политики и 
не осуществляя критический подход к ним, сделаем попытку дать собственную трактовку указанного выше понятия. По нашему мнению, молодежная политика - это совокупность взаимодействия и установление отношений субъектов такой политики в рамках осуществления мер нормативно-правового, финансово-экономического, организационноуправленческого, информационно-аналитического, научного, кадрового характера, направленных на создание условий для оптимально эффективной самореализации молодежи.

Осмысливая современную молодежную политику, важно пересмотреть систему традиционных взглядов на новые поколения, на систему межпоколенческих отношений, на их роль и значение для социальноэкономического развития нашей страны.

В целях научного обоснования, разработки новых подходов к исследованию молодежной политики необходим скрупулезный сбор унифицированных количественных данных, обновленная система качественных показателей состояния детей и молодежи для объективного анализа их положения в нашей стране, определения научно обоснованных тенденций социализации и социокультурного развития новых поколений.

\section{Современные проблемы молодежи}

Для того, чтобы понять, с какими проблемами сталкиваются сегодня молодые люди, проживающие на территории Российской Федерации, целесообразно вести соответствующий общероссийский мониторинг. Какие же наиболее общие проблемы волнуют молодое поколение? Международным центром семьи, молодежи и детей с участием автора настоящей публикации было проведено социологическое исследование, подробные результаты которого были опубликованы в книге «Молодежь и молодежная политика в России: теоретические основы и современная практика» выпуск I (Молодежь и молодежная ..., 2014). Интервьюерам предлагалось назвать две основные проблемы, с которыми им пришлось столкнуться в 2013 г. Среди набора таких проблем были: недобросовестная работа ЖКХ; некомпетентный руководитель; материальные и финансовые трудности; кризис в обществе и личной жизни; загрязнение окружающей среды; отсутствие мест проведения досуга; безработица; низкая заработная плата; отсутствие детских садов и яслей; отсутствие работы по профессии; развод; плохое здоровье; отсутствие собственной жилплощади; некачественное здравоохранение; сокращение штатов; алкоголизация молодежи; маленькие стипендии; наличие большого количества бездомных собак и другие.

Подчеркнем, что молодежь часто воспринимает имеющиеся в стране, регионе, районе проблемы как собственные нерешенные задачи, потому что они касаются всех и конкретно каждого. Но есть такие проблемы, ко- 
торые являются наиболее острыми. Для их определения респондентам из всех федеральных округов задавался идентичный вопрос: «Какие проблемы беспокоят Вас больше всео в Вашем городе, районе, поселке?». Исходя из важности данных проблем, их рейтинг оказался следующим:

1 место - инфляция, рост цен;

2 место - экологические проблемы;

3 место - коррупция;

4 место - состояние социальной сферы;

5 место - пассивность граждан, их безразличие к происходящим процессам;

6 место - пьянство среди молодежи;

7 место - расслоение общества на бедных и богатых;

8 место - рост преступности;

9 место - безработица, угроза потерять работу;

10 место - разводы.

Как видно из анализа представленных данных, молодежь тревожит, прежде всего, «инфляция, рост цен». На наличие такой проблемы указали более половины молодых людей из числа респондентов, опрошенных в 8 федеральных округах. Значит, эта проблема всей России. Очевидно, именно данная проблема должна стать во главу внутренней политики Российского государства в современных условиях и решаться с участием молодежи.

Молодежи не безразлично, что происходит в местах ее проживания. Вряд ли еще десятилетия назад молодых людей так остро тревожили проблемы экологии. В современных условиях, по мнению респондентов, такие проблемы серьезно беспокоят молодое поколение. В рейтинге ответов проблемы экологии оказались на 2 месте. Они тревожат фактически каждого третьего молодого человека. Наименее всего данные проблемы волнуют молодежь, проживающую в Северокавказском и Приволжском федеральных округах. А больше всего такие проблемы беспокоят представителей молодого поколения, проживающего в Южном и Сибирском федеральных округах.

На 3 место «тревожащих» молодежь проблем вышла «коррупция». Коррупция особенно волнует молодежь, проживающую в Центральном и Северокавказском федеральных округах. Очевидно, такое явление либо действительно пустило могучие корни, либо объявленная «война» против коррупции настолько малоэффективна, что не приносит никаких конкретных положительных результатов. Подчеркнем, что наименее всего из обследованных территорий проблемы коррупции волнуют молодежь, проживающую в Уральском и Дальневосточном федеральных округах.

Следует также отметить, что современное молодое поколение пере- 
живает и за состояние социальной сферы. Данная проблема в рамках указанного выше социологического исследования вышла в рейтинге таких проблем на 4 место. Она тревожит $29,8 \%$ российской молодежи. Эта проблема остро стоит, прежде всего, в Северо-Кавказском федеральном округе. На ее наличие указали $39,7 \%$ респондентов из числа молодежи. Это наибольший процент среди молодых людей, опрошенных в восьми федеральных округах.

На 5 месте в рейтинге беспокоящих молодежь проблем оказалась пассивность граждан, их безразличие к происходящим процессам. Скорее всего пассивная позиция касается всех сфер жизни населения, в том числе молодежи.

Стоит также отметить такую тревожащую молодое поколение проблему, как пьянство среди молодежи. Данная проблема вышла на 6 место в рейтинге обозначенных проблем. Безусловно, проблема пьянства должно настораживать гражданское общество и органы местного самоуправления. Ее необходимо решать комплексно и целенаправленно, создавая рабочие места для молодежи, оказывая ей поддержку в реализации позитивных инициатив, организуя работу, направленную на популяризацию здорового образа жизни, открывая дополнительное количество спортивных секций, в том числе общедоступных, бюджетных, бесплатных. Именно эти меры предложили сами молодые люди, проживающие в разных субъектах Российской Федерации в ходе заполнения анкет, ставших важной составной частью проведенного социологического исследования.

\section{Выводы}

Молодежь является особой социальной группой, которой свойственны новаторские идеи, инициативы и творческий порыв. Важно вовремя поддержать ее и создать условия для реализации молодыми людьми своих позитивных планов. К сожалению, молодежные инициативы не всегда бывают поддержанными. В результате степень самореализации молодежи остается недостаточной, что может явиться причиной многих жизненных проблем. Здесь и нужна для «новой» молодежи существенным образом обновленная, современная молодежная политика.

\section{СПИСОК ЛИТЕРАТУРЫ}

Государственная молодежная политика: российская и мировая практика реализации в обществе инновационного потенциала новых поколений (2013) [Электронный ресурс] / под общ. ред. Вал. А. Лукова. М. : Издво Моск. гуманит. ун-та. 718 с. URL: http://hdirussia.ru/assets/files/Books/ State-Youth-Policy.pdf (дата обращения: 13.08.2016). 
Жулковска, Т., Ковалева, А. И., Луков, В. А. (2003) «Ненормальные» в обществе : Социализация людей с ограниченными интеллектуальными возможностями. Москва-Щецин : Изд-во Моск. гуманит. ун-та. 432 с.

Ильинский, И. М. (1999) Молодежь планеты: глобальная ситуация в 90-х годах, тенденции и перспективы / И. М. Ильинский и др.; рук. автор. кол. и науч. ред. И. М. Ильинский. М. : Изд-во Ин-та молодежи ; Голос. 323 с.

Ильинский, И. М. (2001) Молодежь и молодежная политика : Философия. История. Теория. М. : Голос. 694 с.

Ильинский, И. М. (2005) Молодежь как будущее России в категориях войны // Знание. Понимание. Умение. №3. С. 5-17.

Ильинский, И. М. (2006) Образование, Молодежь, Человек. Кн. 1. М.: Изд-во Моск. гуманит. ун-та. 560 с.

Ильинский, И. М. (2008) Образ российской молодежи в современном мире: самосознание и социокультурные ориентиры // Alma mater (Вестник высшей школы). №2. С. 3-6.

Ильинский, И. М. (2009b) О критериях эффективности молодежной политики // Наша молодежь. №1. С. 5-7.

Ильинский, И. М. (2009а) Молодежь в стратегиях будущего России и уроки проигранной холодной войны // Русский интеллектуальный клуб. Кн. 6. М. : Социум. С. 7-15.

Ильинский, И. М. (2009с) Образование. Молодежь. Человек : (статьи, интервью, выступления). Кн. 2. М. : Изд-во Моск. гуманит. ун-та. 530 с.

Ковалева, А. И. (1995) Школа как институт социализации учащейся молодежи // Молодежь в современном российском обществе : налуч. сессия Института молодежи, 22-23 февр. 1995 г. М. 120 с. С. 57-61.

Ковалева, А. И. (1996) Социализация личности: норма и отклонение / Ин-т молодежи. М. 224 с.

Ковалева, А. И. (2001) Личность и общество: Лекции по социологии : учеб. пособие. М. : Социум. 104 с.

Ковалева, А. И. (2003) Концепция социализации молодежи: нормы, отклонения, социализационная траектория // Социол. исследования. 2003. №1. С. 109-114.

Ковалева, А. И. (2004) Социализация // Знание. Понимание. Умение. № 1. С. 139-143.

Ковалева, А. И. (2006а) Социализация нетипичной молодежи // Знание. Понимание. Умение. 2006. № 1. С. 187-187.

Ковалева, А. И. (2006b) Личность молодого человека // Знание. Понимание. Умение. № 2. С. 221-222.

Ковалева, А. И. (2007) Проблемы результативности социализации молодежи в изменяющемся обществе // Вестник Международной академии наук (Русская секция). № 1. С. 73-77. 
Ковалева, А. И., Богданова, В. В. (2012) Траектории социализации : монография. М. : Изд-во Моск. гуманит. ун-та. 184 с.

Ковалева, А. И., Луков, В. А. (1999) Социология молодежи : Теоретические вопросы. М. : Социум. 351 с.

Ковалева, А. И., Луков, В. А. (2012) Социализация: социальнофилософский, социологический и социально-психологический аспекты понимания // Философия и культура. № 3. С. 27-35.

Лисовский, В. Т. (1998) Динамика социальных изменений (опыт сравнительных социологических исследований российской молодежи) // Coциол. исследования. № 5. С. 99-105/

Лисовский, В. Т. (2000) Духовный мир и ценностные ориентации молодежи России. СПб. : СПбГУП. 508 с.

Луков, В. А. (2007) Воспитание и глобализация : Проблемы социологии воспитания. М. : Флинта : Наука. 144 с.

Луков, Вал. А. (2012) Теории молодежи: Междисциплинарный анализ. М. : «Канон+» РООИ «Реабилитация». 528 с.

Луков, Вл. А., Луков, В. А., Ковалева, А. И. (2006) Уроки Макаренко. М. : Издат. дом «Ключ С». 80 с.

Молодежь и молодежная политика в России: теоретические основы и современная практика (2014) / под общ. ред. А.Д. Плотникова. М. : ООО «РПринто». Вып. 1.164 с.

Молодежь России: воспитание жизнеспособных поколений (1995) : докл. Ком. РФ по делам молодежи / авт. колл.: И. М. Ильинский [и др.] ; Ком. РФ по делам молодежи. М. 256 с.

Молодежь России: тенденции, перспективы (1993) / под ред. И. М. Ильинского, А. В. Шаронова. М. : Молодая гвардия. 215 с.

Kowalowa, A., Łukow, W. (2003) Socjologia młodzieży. Szczecin : WSH TWP. 368 s.

Плотников Александр Дмитриевич - доктор исторических наук, профессор, профессор кафедры социологии Московского гуманитарного университета. Адрес: 111395, Россия, г. Москва, ул. Юности, д. 5. Тел.: +7 (499) 374-60-21. Эл. адрес: rostsentrsem@yandex.ru

Plotnikov Aleksandr Dmitrievich, Doctor of History, Professor, Department of Sociology, Moscow University for the Humanities. Postal address: 5 Yunosti St., 111395 Moscow, Russia. Tel.: +7 (499) 374-60-21. E-mail: rostsentrsem@ yandex.ru 